\title{
MARKETING OF TOURISM REGION AS A NECESSARY CONDITION \\ OF EFFECTIVE MANAGEMENT BY REGIONAL TOURISM
}

Maia Chechelashvili

Doctor of Economics (Ph.D.),

Professor, Georgian Technical University, Tbilisi, Georgia

Lia Berikashvili

Doctor of Economics (Ph.D.),

Professor, Georgian Technical University, Tbilisi, Georgia

Elisabed Malania

Doctor of Technical Sciences,

Professor, Georgian Technical University, Tbilisi, Georgia

\begin{abstract}
The creation of effective tourism management systems at the level of individual regions is one of the most pressing problems in the development of regional tourism. They make it possible to identify and eliminate the shortcomings of the regional tourist infrastructure, increase the popularity and recognition of tourist regions, and streamline the local tourist market. One of the most important functions in the management of regional tourism is the marketing of the tourist region. The article discusses the use of marketing of tourist regions to ensure effective tourism management at the regional level.
\end{abstract}

Keywords: tourism, tourism management, tourist region, marketing of the tourist region.

Regional tourism is a complex system of interconnections and interrelations of various subjects of the tourist market, their interactions at various levels. Such a system is influenced by a variety of factors and processes occurring both within the tourist region and beyond. At present, three dominant factors have the greatest impact on the successful development of tourism at the regional level: 
- market factor - the interpenetration of regional, national and world markets through the liberalization of foreign trade and the removal of protectionist restrictions in the World's framework Trade Organization;

- a competitive factor - increased competition in all the above markets, especially non-price competition - competition in quality of the tourism product and implementing various innovative projects;

- production factor - a gradual transition from fordism to post-fordism as a way of organizing the production of a tourist product which means replacing the mass production of a tourist product with individual (small-scale) production, vertical labor organization - horizontal, low individual responsibility - complicity of the personnel in the production process of creating a tourist product.

Besides these three fundamental factors that directly affect the success of tourism development in a particular tourist region, when managing tourism at the regional level, it is necessary to take into account the existence and impact of many other, often homogeneous, factors. For their analysis and assessment can be used a variety of criteria or signs of classification. One of the options for classifying factors affecting the development of regional tourism is presented in Figure 1.

Figure 1. Factors affecting the development of tourism in the region

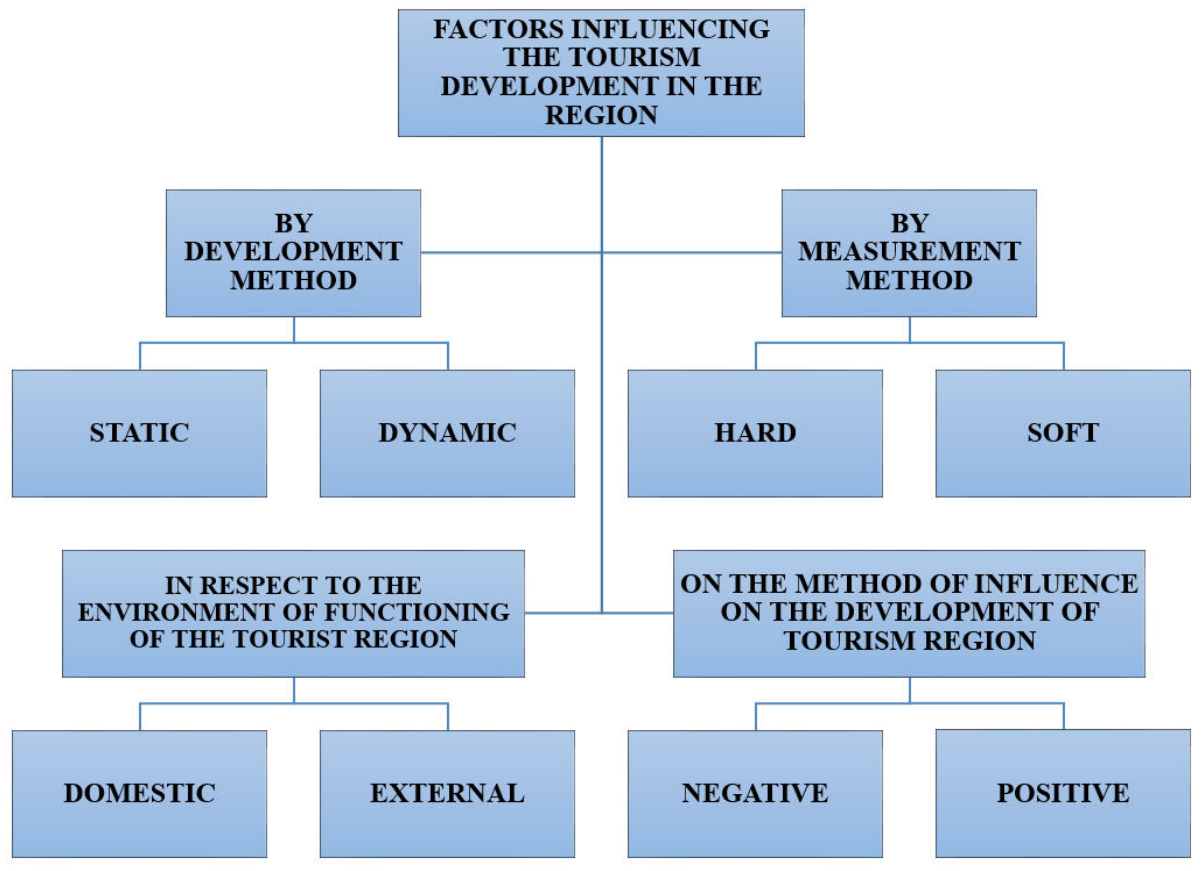


By the method of development, we can divide all factors affecting regional tourism into two sizeable groups: static and dynamic. Static factors include a combination of natural and climatic factors are of lasting, constant value and are adapted by the local population to tourist needs. The climatic and geographical factors of the region include a beautiful and rich nature, climate, topography, underground wealth (healing springs, caves, etc.). Statistical factors can also largely include cultural and historical factors of the region (historical, cultural, architectural, etc.). The group of dynamic factors includes demographic, socioeconomic, material, technical and political factors, which may have an original assessment and change their value in time.

In relation to the functioning environment of the tourist region, it is possible to identify factors of the internal and external environment for the region that interact with each other and have a direct and indirect impact on the development of regional tourism. A qualitative assessment of the factors of the internal environment of the tourist region involves an analysis of the production and resource and personnel potential of the region, the structure of the regional market and regional budget, the development strategy and the material and technical base of the region (accommodation, transport, catering, retail, recreation, etc.) In addition, the internal factors of tourism development in the region include factors characterizing the functioning of the regional tourism market:

- processes of demand, supply and distribution of a regional tourist product;

- the increasing role of market segmentation in connection with the increasing complexity of tourism needs and the emergence of mixed forms of tourism;

- increasing the importance of coordination of activities in tourism and the intensification of globalization processes (the disappearance of national and regional preferences, equalizing the needs and demands of consumers, saving on the scale of production because of standardization of products or services);

- training (increase in the number of workers used in tourism, 
- development of vocational qualifications structure, increasing the importance of vocational training, improving the organization of labor, etc);

- the growing role of private tourism business creating market conditions with a few large operators and a significant number of small tourism companies (tour agents).

Environmental factors of the tourist region have a direct and indirect impact on the development of regional tourism. Directly affect the success of tourism development in the region, external suppliers of goods and services, external consumers, competing regions, financial organizations and transport enterprises.

The following groups of factors indirectly influence the development of regional tourism:

- general economic factors (income level of the population),

- foreign economic activity of states, processes of integration and globalization of the global economy);

- general political factors (stable political situation in the tourist region, type of international relations with regions-suppliers of tourists, the state of the country's trade and balance of payments, international situation);

- scientific and technical factors (the pace of scientific and technological progress,

- the application of his achievements in the practice of tourism, the rational use of material resources and modern technologies);

- demographic factors (age of the region's population increase in the number of single people, childless couples in the region's population, reduction of immigration restrictions, increase in the level of education and culture, esthetic needs of the population).

According to the method of influencing the functioning and development of the tourist region, positive (extensive and intensive) and negative (restraining) groups of factors are distinguished. The positive extensive factors include the increase in the number of employees, the increase in material resources involved in the economic turnover, and the construction of new tourist infrastructure facilities. 
Positive intensive factors will be staff development and technical improvement of the material base based on implementing scientific and technological progress, improving the corporate culture, culture and quality of tourist services, the rational use of resources available in the region, the technologization and computerization of regional tourism. Negative factors that negatively affect the development of the tourist region will include crises, political and financial instability, unemployment and strikes, growth, prices and reduced consumption, unfavorable environmental conditions, toughening of tourist formalities and bankruptcy of tourism companies, etc.

According to the measurement method, they identify two large groups of factors that influence the development of the tourist region: the so-called "hard" and "soft" factors. "Hard" factors mean quantifiable factors oriented to productive resources (land, personnel, capital), production and marketing of products (infrastructure, population and consumption structure), and taxes, subsidies and support programs established by the state. These factors include energy costs and third-party services, wages (including social security contributions) and the availability of labor resources, transportation position, communications and costs, availability of technology, communications and knowhow, proximity to markets and purchasing power of the population, territorial location and infrastructure equipment. "Soft" factors relate to quantitatively difficult-to-measure categories, the level of development of the social environment of the tourist region; "friendliness" of its economy; the stability of the political situation; the regional structure of the economy; the quality of the education and training system; universities and research organizations in the region; attitude to the economy of the main actors in the region - enterprises, politicians, business unions, local administration; the quality of life in the region - quality of housing, cultural and recreational opportunities, etc.

Thus, we can say that a significant number of various factors have a significant influence on the development of tourism at the level of individual regions. Their accounting, control and adaptation to the needs of the tourist region 
is one of the priority tasks of the regional tourism management system. The solution to this problem can only be carried out by a complex managerial impact on the tourism infrastructure of the region and the participants of the regional tourism market in several areas. One of the main directions of managing the development of regional tourism is the marketing of the tourist region, which is part of the national tourism marketing and includes the marketing of domestic, inbound and outbound tourism.

We can define marketing of a tourist region as an activity undertaken with the goal of purposefully creating, maintaining or changing a certain image of a territory and / or behavior of entities external to that territory [1]. It involves the identification or creation of unique properties of the region and affects all participants in the regional tourism market:

- for entrepreneurs in tourism, by creating a sales market - providing the conditions for the activities and qualifications of the workforce;

- for tourists - by informing about the climatic conditions of the region sights and opportunities for recreation;

- for investors - by ensuring streamlined procedures for the sale of property and land, profitability and security of investments, the possibility of exporting profits outside the region, etc.

The major marketing objectives of the tourist region are [1]:

- increasing the competitiveness of tourism industry organizations in the region and organizations from industries related to tourism;

- strengthening identification of residents with their territory of permanent residence;

- attracting to the region consumers and producers of tourist goods and services;

- creation of a positive reputation, a top level of popularity of the region in the tourist market. 
The choice of the direction of marketing activities in the tourist region depends on several circumstances, however, the most common points of application of marketing efforts in the tourist's management region will be:

1. Creation and maintenance of a favorable image of the tourist region. Among potential tourists and all parties interested in the development of regional tourism. For this, the region needs to actively use such marketing tools as advertising (in regional and national mass media), public relations (organizing presentations of the tourist region, taking part in specialized tourism exhibitions and forums), sales promotion (providing discounts on the regional tourist product, manufacturing and distribution souvenir tourism products of the region). An important means of creating and maintaining a favorable image of the tourism region is branding - both the tourism region itself and the tourism product it offers. There are three dominant types of brands: functional brands, image brands and empirical brands [2]. They acquire functional brands to satisfy the functional needs for food, safety, health, movement - while we associate the main consumer associations with the physical characteristics and basic functions of the brand. Such brands imply superior performance or superior economy. Formation and promotion of functional brands requires focusing on resources, product or price position and is mainly used by unique tourist regions of the recreational plan. Brands of the image are created by a set of unique associations and are used in cases where the products are slightly differentiated or it is difficult to assess their quality. Brand-related images add symbolic value by reporting community or achievements. Empirical brands are unique in that they focus on consumer feelings when interacting with the brand. To use them, it is necessary to create a sequence of experiences among consumers and expand the limits of their emotional saturation. We present comparative features of all varieties of brands in table 1 . 
Table 1. Comparative features of all varieties of brands

\begin{tabular}{|c|c|c|c|c|}
\hline BRAND TYPE & $\begin{array}{c}\text { BASIS FOR } \\
\text { DIFFERENTIATION }\end{array}$ & $\begin{array}{c}\text { ACCENT OF } \\
\text { MARKETING }\end{array}$ & $\begin{array}{l}\text { CONSUMER NEED AND } \\
\text { PARTICIPATION }\end{array}$ & $\begin{array}{l}\text { MANAGEMENT } \\
\text { CHELLENGES }\end{array}$ \\
\hline FUNCTIONAL & $\begin{array}{c}\text { EXCELLENT } \\
\text { FUNCTIONING OR } \\
\text { EXCELLENT ECONOMY }\end{array}$ & $\begin{array}{l}\text { PRODUCT, PRICE AND / } \\
\text { OR LOCATION }\end{array}$ & $\begin{array}{l}\text { PHYSIOLOGICAL AND } \\
\text { SAFETY NEEDS: } \\
\text { RELATIVELY LOW } \\
\text { PARTICIPATION }\end{array}$ & $\begin{array}{l}\text { SAVING BASING AT } \\
\text { EXCELLENCE }\end{array}$ \\
\hline FORM & DESIRED IMAGE & COMMUNICATIONS & $\begin{array}{l}\text { SOCIAL NEEDS AND } \\
\text { REQUIREMENTS FOR } \\
\text { RESPECT: FROM } \\
\text { MODERATE TO HIGH } \\
\text { PARTICIPATION }\end{array}$ & $\begin{array}{c}\text { BRAND FOR HERITAGE } \\
\text { OF THE BRAND AND } \\
\text { DYNAMIC } \\
\text { ENVIRONMENTAL } \\
\text { REQUIREMENTS }\end{array}$ \\
\hline EMPIRICAL & $\begin{array}{l}\text { UNIQUE, ATTRACTIVE } \\
\text { EXPERIENCE }\end{array}$ & $\begin{array}{l}\text { SERVICE PRESENTATION } \\
\text { (PLACES AND PEOPLE) }\end{array}$ & $\begin{array}{c}\text { NEEDS FOR SELF- } \\
\text { REALIZATION: FROM } \\
\text { HIGH PARTICIPATION }\end{array}$ & $\begin{array}{l}\text { RISK OF USER } \\
\text { SATURATION }\end{array}$ \\
\hline
\end{tabular}

2. Development and definition of a promising concept for the development of regional tourism based on a comprehensive marketing study of the size and nature of tourist flows in the region and basic tourist preferences regarding a regional tourist product. We present the crucial stages of conducting a comprehensive marketing tourism research at the regional level in Figure 2.

Figure 2 - Stages of an integrated marketing studies of the state of the tourist market in the region

STEP 1. MEASUREMENT OF THE SIZE AND CHARACTERISTICS OF TOURISM FLOWS OF THE REGION

STEP 2. DEPARTURE FROM THE LEAVING FLOW OF TOURISTS WITH SPECIFIC GOALS AND OBJECTIVES

STEP 3. DETERMINING THE PREFERENCES OF TOURISTS

STEP 4. SEGMENTATION OF TOURISTS BY CONSUMER GROUPS

STEP 5. RESEARCH OF THE TOURIST OFFER FOR THE DETERMINATION OF SEGMENTS OF TOURISTS IN THE TOURISM REGION

STEP 6. IDENTIFYING PRIORITY LINES OF ACTIVITY FOR THE DEVELOPMENT OF REGIONAL TOURISM

STEP 7. TRANSFORMATION OF PROGRAM EVENTS FOR THE DEVELOPMENT OF REGIONAL TOURISM IN THE COMPLEX OF METHODICAL RECOMMENDATIONS FOR THE IMPROVEMENT OF TOURISM ACTIVITIES IN THE REGION

STEP 8. EVALUATION OF EFFICIENCY AND SOCIO-ECONOMIC AND ENVIRONMENTAL CONSEQUENCES OF THE SUGGESTED PROGRAM EVENTS 


\section{Conclusion}

Thus, marketing allows the best use of the competitive advantages available in the region, mitigate the negative impact of adverse environmental factors, and ensure the quality and attractiveness of the tourism product. We can use marketing campaigns as separate marketing tools (advertising, public relations, sales promotion), and events. Segmentation of tourist flows and marketing analysis of resources for the development of long-term marketing programs can provide the level of competitiveness in all areas, and at the level of the tourism market.

\section{References:}

1. Berry, L.L. Services Marketing is Different // Business. 1980. - 30 (MayJune),

2. Edgett S., Parkinson S. Marketing for Service Industries: A Review // The Service Industries Journal, July 2013.

3. Levitt T. Marketing for Business Growth. New York: McGraw-Hill, 2014.

4. Zeithaml V.F., Parasuraman F., Berry, L.L. Problems and Strategies in Service Marketing // Journal of Marketing, spring 2015.

5. WTO's Tourism 2020 Vision/ Global Forecast and Profiles of market segments, November 2001. 